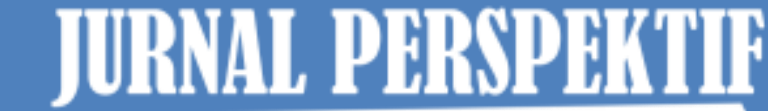

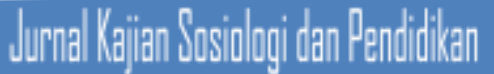

Jurnal Perspektif: Jurnal Kajian Sosiologi dan Pendidikan Vol. 4 No. 3 Tahun 2021

http://perspektif.ppj.unp.ac.id

Email: perspektif@ppj.unp.ac.id

ISSN: 2622-1748 (Online), 2684-902X (Print)

DOI: http://dx.doi.org/10.24036/perspektif.v4i3.496

\title{
Faktor Penyebab Meningkatnya Cerai Gugat Pada Masa Pandemi Covid-19 di Kecamatan Sungai Pagu Kabupaten Solok Selatan
}

\author{
Fitria Afifah $^{1}$, Delmira Syafrini ${ }^{2}$ \\ 1,2 Universitas Negeri Padang \\ Email: fitriaafifah0202@gmail.com, delmirasyafrini@ fis.unp.ac.id
}

\begin{abstract}
Abstrak
Penelitian ini bertujuan untuk menjelaskan faktor-faktor yang menjadi penyebab tingginya cerai gugat pada masa Pandemi Covid-19 di Kecamatan Sungai Pagu, Kabupaten Solok Selatan, hal ini menarik untuk diteliti karena selama 2 tahun terakhir, sejak pandemi Covid-19 angka cerai gugat yang dilakukan oleh istri meningkat. Meningkatnya kasus perceraian yang di ajukan oleh pihak istri kepada pihak suami hal tersebut menjadi persoalan yang menarik karena perceraian seharusnya berasal dari pihak laki-laki melalui cerai talak, meskipun dalam agama perempuan berkah mengajukan perceraian, namun persepsi masyarakat masih menganggap hal ini sebagai sesuatu yang tabu. Jenis penelitian kualitatif dengan tipe penelitian studi kasus jenis studi kasus instrinsik, teknik pemilihan informan yaitu purposive sampling dengan jumlah informan sebanyak 24 orang. Pengumpulan data dilakukan dengan teknik observasi non partisipasi, wawancara mendalam, dan studi dokumentasi yang dianalisis dengan mengacu pada teknik analisis data interaktif yang dikembangkan oleh Miles dan Huberman. Berdasarkan hasil penelitian dapat ditarik kesimpulan bahwa ada beberapa faktor yang menyebabkan meningkatnya cerai gugat pada masa Pandemi Covid-19 di Kecamatan Sungai Pagu Kabupaten Solok Selatan, diantaranya: (1) faktor ekonomi, faktor ini terjadi karena pada masa Pandemi Covid-19 banyak suami yang kehilangan pekerjaannya sehingga tidak memberikan nafkah kepada istri dan karena beban ganda yang dialami perempuan pada saat Pandemi Covid-19. (2) Faktor psikologis, faktor ini terjadi karena selama pandemi Covid-19 suami istri mengalami kejenuhan dan dipengaruhi usia pernikahan yang lebih muda. Selanjutanya cerai gugat yang terjadi sebelum masa Pandemi Covid-19 terjadi akibat perselingkuhan dan terjadinya kekerasan dalam rumah tangga.
\end{abstract}

Kata Kunci: Cerai gugat, Pandemi Covid-19, Perceraian

\section{Abstract}

This study aims to explain the factors that caused the high rate of divorce during the Covid-19 Pandemic in Sungai Pagu District, South Solok Regency by wife increases. The increasing number of divorce cases submitted by the wife to the husband has become an interesting issue because divorce should come from the male side through talak divorce, even though in religion women are blessed to file for divorce, but public perception still considers this as something unusual.The type of qualitative research with the type of research is case study, the type of intrinsic case study, the informant selection technique is purposive sampling with the number of informants as many as 24 people. Was collected document by means of non-participatory observation, in-depth interviews, and documentation studies which were analyzed by referring to the interactive data analysis technique developed by Miles and Huberman.Based on the results of the study, it can be concluded that there are several factors that led to an increase in divorce during the Covid-19 Pandemic in Sungai Pagu District, South Solok Regency, including: (1) economic factors, this factor occurred because during the Covid-19 pandemic many husbands lost his job so he did not provide a living for his wife and because of the double burden experienced by women during the Covid-19 Pandemic. (2) Psychological factors, this factor occurs because during the Covid-19 pandemic husband and wife experience saturation and are influenced by younger marriage ages. Furthermore, the divorce that occurred before the Covid-19 pandemic occurred due to infidelity and the occurrence of domestic violence.

Keywords: Divorce, Covid-19 Pandemic, Divorce 


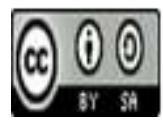

\section{Pendahuluan}

Manusia diciptakan berpasang-pasangan laki-laki dan perempuan untuk saling mengisi satu sama lain yang diwujudkan dalam bentuk perkawinan. Tujuannya untuk membentuk sebuah rumah tangga sakinah, mawadah dan warahmah.Dilihat dari sisi sosiologis perkawinan adalah suatu bentuk kerja sama kehidupan pria dan wanita dalam kehidupan suatu masyarakat dibawah suatu peraturan yang khas (khusus) yang memiliki ciri-ciri tertentu, yaitu pria bertindak sebagai suami dan perempuan bertindak sebagai istri, yang keduanya dalam ikatan yang sah (Rais, 2010:76).

Menurut Hurlock (Sari, 2014:16) perceraian merupakan kulminasi dari penyesuaian perkawinan yang buruk dan terjadi apabila suami dan istri sudah tidak mampu lagi mencari cara penyelesaian masalah yang dapat memuaskan kedua belapihak. Menurut UndangUndang No 1 tahun 1994 Pasal 16, perceraian terjadi apabila antara suami-istri yang bersangkutan tidak mungkin lagi didamaikan untuk hidup rukun dalam suatu rumah tangga. Pada pasal 18 disebutkan perceraian terhitung pada saat perceraian itu dinyatakan di depan sidang pengadilan. Pengadilan berusaha melakukan perdamaian pada pasangan yang hendak bercerai dan perceraian terjadi bila pengadilan tidak berhasil mendamaikan keduanya.

Berbicara tentang perceraian, di Indonesia Tingkat perceraian mengalami peningkatan bahkan pada masa Pandemi Covid-19. Pandemi Covid-19 atau Virus Corona mengubah berbagai aspek kehidupan masyarakatdan rumah tangga. Apalagi setelah pemerintah memberlakukan kebijakan lockdown atau pembatasan kegiatan keluar rumah secara menyeluruh, semua aktivitas yang dapat menyebabkan terciptanya kerumunan atau perkumpulan di hentikan sementara seperti pergi bekerja, sekolah, beberapa restoran tempat usaha disarankan untuk ditutup sehingga semua aktivitas dilakukan di dalam rumah. Masyarakat hanya boleh keluar rumah jika ada keperluan yang sangat mendesak saja. Mereka bertemu pasangannya hampir setiap hari selama lockdown, sehingga muncul rasa bosan di antara mereka.

Pandemi Covid-19 menghambat kegiatan sehari-hari kegiatan tersebut terpaksa dilakukan dari rumah sehingga membuat interaksi keluarga menjadi intens dari hari-hari sebelumnya. Beberapa keluarga merasakan dampak positif dari hal ini. Namun disamping itu, ada pula beberapa keluarga yang merasakan dampak negatif dari pandemi ini. Pandemi Covid-19 menimbulkan potensi perceraian bagi sebagian besar keluarga, kondisi Pandemi Covid-19 menghambat kegiatan sehari-hari kegiatan tersebut Covid-19 menciptakan batasan kaku antara keluarga inti dan orang-orang di luar keluarga. Batasan antara pekerja dan kehidupan rumah tangga pun menjadi kabur dan memberikan peluang baru terjadinya konflik seperti intensifikasi peran orang tua dan penyebab stres lainya seperti pengangguran dan pengurangan pendapatan. Banyak sekolah ditutup sehingga memberikan peran baru bagi orang tua sebagai guru sehingga meningkatkan stres kerja, terutama bagi wanita yang bertanggung jawab besar atas tugas ini. Dari intensitas kegiatan keluarga di dalam rumah dan stres yang berlebihan selama pandemi berakibat kepada peningkatan konflik yang berujung kepada perceraian (Apriasari \& Al-jannah, 2021).

Meningkatnya perceraian di Indonesia selama Pendemi Covid-19 dijelaskan oleh Direktur Jenderal Badan Peradilan Agama Mahkamah Agung (Dirjen Badilag MA) Aco Nur, 
Fitria Afifah, Delmira Syafrini Faktor Penyebab Meningkatnya Cerai Gugat Pada Masa Pandemi Covid-19 di Kecamatan Sungai Pagu Kabupaten Solok Selatan

menjelaskan bahwa selama Pandemi Covid-19 total perceraian di seluruh Indonesia mengalami peningkatan. Hal itu desebabkan adanya pembatasan sosial berskala besar (PSBB) yang diterapkan hampir di seluruh wilaya di Indonesia. Aco memaparkan bahwa saat awal penerapan PSBB pada April dan Mei 2020, perceraian di Indonesia di bawah 20 ribu kasus. Namun pada Juni dan Juli 2020 jumlah perceraian meningkat menjadi 57 ribu kasus. Dari data di atas menjelaskan bahwa kasus perceraian di Indonesia mengalami peningkatan pada tahun terjadinya Pandemi Covid-19 yaitu tahun 2020, sehingga perlu diteliti lebih lanjut apa penyebab meningkatnya perceraian di Indonesia (detik.com, 2018).

Berdasarkan data perceraian di Indonesia, hal yang sama juga terjadi di Kabupaten Solok Selatan. kasus perceraian akibat Pandemi Covid-19 di Kabupaten Solok Selatan juga mengalami peningkatan yang signifikan, Dari tahun 2019 sebelum terjadinya Pandemi hingga tahun 2020 saat terjadinya Pandemi Covid-19. Seperti data yang terdapat di Pengadilan Agama Muara Labuh berikut ini:

Tabel 1. Data perceraian di Kabupaten Solok Selatan tahun 2019-2020:

\begin{tabular}{ccccc}
\hline No & Tahun & Cerai Talak & Cerai Gugat & Total \\
\hline 1. & 2019 & 81 & 225 & 306 \\
\hline 2. & 2020 & 88 & 250 & 338 \\
\hline
\end{tabular}

Sumber: Kantor Pengadilan Agama Muara Labuh, Kabupaten Solok Selatan.

Berdasarkan tabel di atas terlihat bahwa angka perceraian di Kabupaten Solok Selatan sebelum terjadi Pandemi dan saat tahun terjadinya Pandemi mengalami peningkatan yang sangat dratis. Pada tahun 2020 angka cerai cukup tinggi di bandingkan tahun sebelum terjadinya Pandemi Covid-19. Namun menariknyaangka cerai gugat yang diajukan oleh istri justru lebih tinggi dari angka cerai talak yang dilakukan oleh suami. Seiring dengan terjadinya wabah Pandemi Covid-19, banyak data yang menyebutkan tingginya kasus cerai gugat atau cerai yang di ajukan oleh istri bukan suami. Hal ini bertolak belakang dengan persepsi masyarakat yang menganggap bahwa suami yang memiliki hak prerogatif untuk menceraikan istrinya.

Pada masa Pandemi Covid-19 di Solok Selatan, Kecamatan yang tingkat perceraian tertinggi pada tahun terjadinya Pandemi Covid-19 yaitu di Kecamatan Sungai Pagu. Berikut data kasus perceraian di Kabupaten solok Selatan per Kecamatan pada tahun 2020:

Tabel 2. Data perceraian di Kabupaten Selatan per Kecamatan pada tahun 2020

\begin{tabular}{llccc}
\hline No & \multicolumn{1}{c}{ Kecamatan } & $\begin{array}{c}\text { Cerai } \\
\text { Talak }\end{array}$ & $\begin{array}{c}\text { Cerai } \\
\text { Gugat }\end{array}$ & Jumlah \\
\hline 1. & Pantai Cermin Kab. Solok & 5 & 23 & 28 \\
\hline 2. & Koto Parik Gadang di Ateh & 19 & 46 & 65 \\
\hline 3. & Sungai Pagu & 22 & 63 & 85 \\
\hline 4. & Pauh Duo & 13 & 38 & 51 \\
\hline 5. & Sangir & 16 & 52 & 68 \\
\hline 6. & Sangir Jujuan & 4 & 9 & 13 \\
\hline 7. & Sangir Batang Hari & 4 & 9 & 13 \\
\hline 8. & Sangir Balai Janggo & 5 & 10 & 15 \\
\hline & Jumlah & 88 & 250 & 338 \\
\hline
\end{tabular}

Sumber: Kantor Pengadilan Agama Muara Labuh, Kabupaten Solok Selatan. 
Penelitian yang relevan dengan penelitian ini adalah penelitian telah dilakukan oleh beberapa peneliti sebelumnya, diantaranya: Penelitian oleh Abdilah Wahab dan Rifqi awati Zahara, dengan judu "Analisis Yuridis Terhadap Faktor-faktor Penyebab Tingginya Tingkat Cerai Gugat di Pengadilan Agama Kabupaten Kediri". Hasil penelitian ini adalah faktor penyebab tingginya tingkat perceraian di Kediri yaitu faktor ekonomi, faktor moral, faktor ikut campur pihak ketiga dan faktor tempat tinggal. (Wahab, 2012).

Penelitian oleh Isnawati Rais Fakultas Syariah dan Hukum UIN Syarif Hidayatullah jakarta. Dengan judul "Tingginya Angka Cerai Gugat (Khulu') di Indonesia: Analisis Kritis terhadap Penyebab dan Alternatif Solusi Mengatasinya." Hasil penelitian Di Jakarta selatan Penyebab tingginya angka cerai gugat adalah salah Kemandirian ekonom membuat perempuan berani mengambil keputusan untuk bercerai. Adapun faktor utama yang menyebabkan istri berani mintak cerai adalah ketidak harmonisan. (Isnawati Rais, 2014).

Persamaan penelitian ini dengan penelitian terdahulu adalah sama-sama menganalisis faktor penyebab tingginya angka perceraian. Pada penelitain pertama membahas pengajuan cerai yaitu dari pihak laki-laki, sedangkan penelitian yang kedua dan ketiga cerai diajukan oleh pihak perempuan. Perbedaan penelitian ini dengan penelitian sebelumnya adalah pertama lokasi penelitian yang dilakukan berbeda dengan penelitian sebelumnya, kedua kondisi masyarakat pada penelitian ini tentu juga akan berbeda dengan penelitian sebelumnya karena kita tahu setiap daerah mempunyai ciri khas kebudayaan masyarakat yang beragam, ketiga waktu penelitian ini tentu berbeda dengan penelitian sebelumnya. Penelitian sebelumnya dilakukan kisaran tahun sebelum pandemi Covid-19 terjadi di Indonesia, sementara penelitian ini dilakukan pada masa pandemi Covid-19, apalagi data menunjukkan angka perceraian tertinggi terjadi pada tahun 2019-2020 dimana tahun tinggi angka pandemi Covid-19 di Indonesia. Asumsi peneliti dari perbedaan penelitian ini dengan penelitian sebelumnya dimana lokasi, waktu, dan suasana yang berbeda akan menghasilkan temuan penelitian yang berbeda pula.

Berdasarkan tabel di atas dapat diketahui bahwa pada tahun terjadinya Pandemi Covid19, kasus perceraian tertinggi terjadi di Kecamatan Sungai Pagu. Kecamatan ini menjadi Kecamatan dengan kasus perceraian tertinggi selama tahun terjadinya Pandemi Covid-19 di Kabupaten Solok Selatan. Bentuk perceraian juga didominasi oleh cerai gugat yang diajukan oleh istri, bukan cerai talak. Data menyebutkan bahwa jumlah angka cerai gugat per Kecamatan dimana Kecamatan tertinggi adalah Kecamatan Sungai Pagu, dimana pada tahun terjadinya Pandemi Covid-19 di Kecamatan Sungai Pagu terdapat 63 kasus cerai gugat.

Tingginya angka cerai gugat pada masa Pandemi ini menjadi kajian yang menarik untuk di teliti, karena penelitian sebelumnya membahas tentang penyebab tingginya cerai gugat tetapi sebelum masa pandemi, dan penelitian ini menfokuskan faktor penyebab tingginya cerai gugat pada masa Pandemi Covid-19, hal ini tentunya menjadi keunikan sendiri dari penelitian ini. Selain itu alasan penelitian ini menjadi hal menarik untuk di teliti adalah karena dalam budaya masyarakat Minangkabau lazimnya suami yang dianggap berhak menjatuhkan talak kepada istri, meskipun secara agama cerai gugat dibolehkan dengan persyaratan tertentu. Berdasarkan latar belakang diatas maka penelitian ini bertujuan untuk menjelaskanfaktor penyebab meningkatnya kasus cerai gugat Pada Masa Pandemi Covid-19 di Kecamatan Sungai Pagu Kabupaten Solok Selatan. 


\section{Metode Penelitian}

Penelitian ini adalah penelitian kualitatif dengan tipe penelitian studi kasus jenis studi kasus instrinsik, Dalam penelitian ini menggunakan tipe studi kasus intrinsik karena dalam penelitian faktor penyebab tingginya cerai gugat perhatian peneliti terfokus dan ditujukan untuk mengerti lebih baik aspek-aspek intrinsik dari suatu kasus perceraian. Teknik pemilihan informan yaitu purposive sampling dengan jumlah informan sebanyak 24 orang. Pengumpulan data dilakukan dengan cara observasi non partisipasi, wawancara mendalam, dan studi dokumentasi yang dianalisis dengan mengacu pada teknik analisis data interaktif yang dikembangkan oleh Miles dan Huberman.

\section{Hasil dan Pembahasan}

\section{Faktor Penyebab Meningkatnya Cerai Gugat Pada Masa Pandemi Covid-19.}

Selama pandemi Covid-19 terjadi peningkatan jumlah kasus perceraian (Wijayanti, 2021), berdasarkan data dari Mahkamah Agung, suami istri yang melakukan pendaftaran perceraian yang awalnya berjumlah 20 ribu kasus pada periode April dan Mei 2020 mengalami peningkatan menjadi 57 ribu pada periode Juni dan Juli 2020. Dilansir dari (Suara.com, 2020) pada bulan Juni dan Juli 2020, jumlah kasus gugatan cerai melonjak hingga 80\% yang diajukan ke Pengadilan Agama mayoritas diajukan oleh pihak istri. Salah satu daerah yang merasakan peningkatan kasus cerai gugat adalah Kabupaten Solok Selatan, dimana dampak buruk dari adanya pandemi covid-19 ini merambah semua sektor, bukan hanya sektor publik namun sektor domestik juga ikut merasakan imbasnya.

Seperti diberitakan oleh beberapa media masa, tentang banyaknya kasus perceraian di tengah pandemi covid-19, dilansir dari (Topsatu.com, 2020) tercatat sejak september 2020 pengadilan agama Muara Labuh menerima perkara perceraian sebanyak 289 perkara, dimana cerai gugat 219 perkara dan cerai talak 70 perkara, berdasarkan data perceraian oleh pengadilan agama Muara Labuh tercata berkisaran 20-30 kasus cerai gugat tiap bulannya pada masa pandemi covid-19. Jika dibandingkan dengan sebelum adanya pandemi covid-19 angka perceraian Solok Selatan relatif stabil, dilansir dari (republika.co.id, 2017) tercatat 112 pasangan mengajukan cerai gugat ke pengadilan agama Muara Labuh, sedangkan pada tahun 2018 cerai gugat di Kabupaten Solok Selatan berjumlah 128 kasus. Meningkatnya kasus cerai gugat juga ditemukan di Kecamatan Sungai Pagu Kabupaten Solok Selatan diperoleh data bahwa angka cerai gugat pada masa Pandemi Covid-19 meningkat, dimana pada tahun 2018 angka cerai gugat hanya terdapat 189 kasus, tahun 2019 terdapat 306 kasus, dan pada tahun 2020 tedapat 338 kasus, berdasarkan data diatas terlihat bahwa adanya peningkatan kasus cerai gugat selama masa Pandemi Covid-19 di Kabupaten Solok Selatan Khususnya Kecamatan Sungai Pagu disebabkan oleh beberapa faktor yang berbeda dengan sebelum masa Pandemi Covid-19 diantaranya:

\section{Faktor-Faktor Penyebab Cerai Gugat Pada Masa Pandemi Covid-19}

\section{Faktor Ekonomi}

Masalah ekonomi memang masih menjadi pemicu konflik dominan bagi suami istri ada atau tidaknya pandemi Covid-19, namun dengan adanya pandemi Covid-19 ini terlebih memberi dampak negatif dalam aspek ekonomi keluarga sehingga kelangsungan ekonomi rumah tangga mengalami keterpurukan, implikasi dari pembatasan sosial adalah hilangnya atau berkurangnya pendapatan keluarga, misalnya akibat PHK besar-besaran oleh 
Fitria Afifah, Delmira Syafrini Faktor Penyebab Meningkatnya Cerai Gugat Pada Masa Pandemi Covid-19 di Kecamatan Sungai Pagu Kabupaten Solok Selatan

perusahaan, mengurangnya daya beli masyarakat, bahkan pelaku bisnis dan usaha menengah yang mengalami kerugian. Imbasnya memicu konflik antara suami istri dan berakhir dengan perceraian, adapun meningkatnya kasus percerai pada masa Pandemi Covid-19 di Kecamatan Sungai Pagu Kabupaten solok selatan yang disebakan oleh faktor ekonomi sebagai berikut:

\section{Suami Tidak Memberikan Nafkah}

Akibat Pandemi yang melanda dan dikeluarkannya kebijakan PSBB oleh pemerintah memberikan dampak yang signifikan terhadap pola kehidupan masyarakat. Masyarakat dilarang berinteraksi di luar rumah dan keluar kota, hal tersebut menyebabkan penurunan pendapatan ekonomi diberbagai sektor kehidupan, Kecamatan Sungai Pagu yang merupakan Kecamatan yang mayoritas masyarakatnya bergantung pada sektor pertanian, dan bekerja pada perusahaan seperti PT SJAL dan PT Mitra Kerinci merasakan dampak dari Pandemi Covid-19 yang menyebabkan daya beli menurun, dan terjadinya PHK oleh perusahaan. Pandemi Covid-19 menyebabkan hilangnya pekerjan oleh suami sebagai tulang punggung keluarga sehingga tidak memberikan bafkah lagi kepada keluarga, seperti yang diungkapkan oleh ibu WY tidak sanggup menahan masalah sehingga meminta cerai. Berikut ungkapan wawancara dari ibu WY:

“...semennjak suami ibu di PHK oleh PT Mitra kerinci yang mengurangi karyawan dampak dari pandemi Covid-19, Suami ibuk tidak lagi memberi nafkah, dia pergi dan pulang sesuka hatinya, tidak ada tanggung jawab, dan mentelantarkan anak-anak dengan tidak memberi uang jajan dan biaya pendidikan". (Wawancara, Tanggal 7 Mei 2021).

Berdasarkan observasi peneliti pada tanggal 7 Mei di Kecamatan Sungai Pagu Kabupaten Solok selatan suami yang bekerja di PT Mitra Kerinci sebagai salah satu perusahaan yang ada di Kabupaten Solok Selatan adalah tempat mayoritas suami mencari nafkah, begitu juga di Kecamatan Sungai Pagu suami merupakan tulang punggung keluarga menggantungkan mata pencariannya bekerja sebagai karyawan pada PT Mitra kerinci, namun akibat pandemi Covid-19 PT Mitra Kerinci sebagai sumber mata pencarian keluarga mengalami pengurrangan karyawan hal itu menyebabkan di PHK nya karyawan sehingga berdampak pada ketidakmapuan seorang suami memberikan nafkah kepada istri ataupun keluarga.

Berdasarkan informasi dari beberapa informan di atas dapat terlihat bahwa alasan istri menggugat cerai suaminya dikarenakan tidak mendapatkan nafkah dari suami yang akan mengakibatkan istri tidak mampu lagi menahan apa yang dirasakan dan membiayai anak dengan usaha sendiri sehingga pihak istri menganggap suami sudah melalaikan tugasnya sebagai pencari nafkah dalam keluarga. Jika dikaikan dengan kondisi ekonomi yang melanda selama Pandemi Covid-19 ini membuat istri susah mencari uang tambahan untuk membiayai hidup sehingga pihak istri menggugat cerai suaminya.

\section{Istri mendapatkan Beban ganda}

Meningkatnya kasus cerai gugat juga ditemukan di Kecamatan Sungai Pagu Kabupaten Solok Selatan salah satu faktor penyebab meningkatnya angka perceraian di Kecamatan Sungai pagu akibat dari masalah ekonomi yang mengalami kemerosotan pada masa Pandemi Covid-19, perceraian karena konflik dalam rumah tangga yang disebabkan oleh masalah ekonomi pada saat Pandemi Covid-19 merupakan sesuatu yang saling berhubungan. Hal tersebut terjadi karena banyak suami terkena pemutusan hungan kerja (PHK), sehingga 
berdampak pada sektor perekonomian keluarga, kondisi ini akan memicu stress dan emosi pada pihak suami karena memikirkan biaya hidup sehari-hari.

Cerai gugat pada masa pandemi juga terjadi terhadap beberapa pasangan suami istri di Kecamatan Sungai Pagu, meningkatnya kasus cerai gugat di Kecamatan Sungai Pagu merupakan akibat dari tidak bekerjanya suami sehingga istri mendapatkan peran ganda, istri yang sehari-hari mengurus rumah tangga juga bekerja untuk memenuhi kehidupan seharisehari, sedangkan suami tidak berusaha mencari pekerjaan lain selain bekerja di PT Mitra Kerinci dan bekerja sebagai petani yang pada masa pandemi mengalami kenaikan harga pupuk sehingga berdampak pada tidak mampunya petani bercocok tanam. Istri yang membagi waktu bekerja dirumah mengurus keluarga dan juga bekerja di sektor publik merasa seorang suami sudah tidak memenuhi tanggung jawab lagi sebagai kepala keluarga, seperti yang di ungkapkan oleh ibu DA salah satu informan yang mencerai gugat suaminya, ibu DA mengngkapkan bahwa:

“...ibu tidak ada diberikan lagi uang semenjak suami ibu berhenti bekerja di PT Mitra Kerinci, padahal ibu butuh biaya, oke dia tidak ada kerja karna dipecat, tapi setidaknya ada usaha untuk mencari pekerjaan lain, dia kan sebagau tulung punggung keluarga, ditambah ibu bekerja mencuci pakaian orang sekaligus mengurus rumah tangga, suami ibu ini tidak ada merasa bersalah sedikitpun, kadang pulang ibu mencuci pakaian orang lain suami ibu ini minta uang beli rokoknya dengan marah-marah, lantaran itu ibu tidak menerima lagi, lalu ibu gugat lah suami ibu bercerai..."

Berdasarkan informasi dari beberapa informan di atas dapat terlihat bahwa alasan istri menggugat cerai suaminya disebakan oleh faktor ekonomi selama Pandemi Covid-19, istri mendapatkan peran ganda, dimana istri yang sebelumnya hanya bekerja sebagai ibu rumah tangga namun pada masa pandemi juga bekerja untuk mencari nafkah keluarga, dikarenakan tidak mendapatkan nafkah dari suami dan suami tidak membantu pekerjaan rumah disaat istri bekerja diluar mengakibatkan istri tidak mampu lagi menahan apa yang dirasakan dan membiayai anak dengan usaha sendiri sehingga pihak istri menganggap suami sudah melalaikan tugasnya sebagai pencari nafkah dalam keluarga.

Jika didalam hubungan perkawinan teori Homans menjelaskan bahwa tidak terjadi pertukaran antara hak dan kewajiban didalam hubungan suami istri. Tidak terjadi sebuah keseimbangan dalam proses pertukaran dan ada satu pihak yang dirugikan dan berujung pada perceraian. Jika dalam rumah tangga pihak istri dan suami salah satunya tidak menerima imbalan yang diinginkan maka akan terjadi ketidakadilan dan disfungsi keluarga. Jika cost dan reward yang diberikan yaitu hak dan kewajiban, dimana hak istri memperoleh nafkah dan kewajiban suami memberikan nafkah bukan istri yang mendapatkan beban ganda dalam rumah tangga. Maka ketika kedua bela pihak memberikan cost dan reward dijalankan dan diberikan maka hubungan suami istri akan berjalan dengan baik. Sebaliknya hak dan kewajiban tidak seimbang atau tidak adil maka hubungan suami-istri akan berjalan tidak harmonis, karena terdapat ketidakadilan atau salah-satu pihak yang merasa dirugikan, maka hal tersebut akan berujung pada perceraian.

\section{Faktor Psikologis}

Pandemi Covid-19 selain berdampak pada ekonomi masyarakat juga berdampak pada meningkatnya angka perceraian di Kecamatan Sungai Pagu Kabupaten Solok Selatan, selain faktor ekonomi faktor lain yang menyebebakan peningkatan cerai gugat oleh istri di 
Kecamatan Sungai Pagu disebabkan oleh faktor Psikologis, Swasta dan (Handoko, 2000:77) berpendapat faktor internal adalah faktor psikologis yang berasal dari proses interen dalam diri individu, dan sangat berpengaruh terhadap perilaku seseorang. Dimana faktor perilaku keluarga khususnya suami istri cukup berpengaruh pada peningkatan angka cerai gugat di Kecamatan Sungai Pagu, berikut faktor Psikologis yang menyebabkan meningkatnya cerai gugat pada masa pandemi Covid-19 di Kecamatan Sungai Pagu:

\section{Muncul Rasa Jenuh}

Pandemi Covid-19 mewajibkan masyarakatnya untuk tidak keluar rumah atau membatasi aktivitas di luar rumah, pasangan suami istri pada masa pandemi selama masa Pandemi Covid-19 menghadapi beberapa permasalahan, diantaranya salah satu muncul rasa jenuh terhadap pasangan suami istri dikarenakan harus terkurung di dalam rumah dalam jangka waktu yang lama, tanpa ada aktiivitas loain yang dianggap menyenangka, begitu juga yang terjadi di Kecamatan Sungai Pagu terhadap meningkatnya cerai gugat pada masa Pandemi Covid-19, seperti yang diungkapkan oleh ibu WD:

“...Ibu menggugat suami ibu bercerai karena dirumah bertemu tiap hari, yang suami ibu ini orangnya emosian, dia seperti boisan atau jenuh dengan ibu beserta anak ibu, apalagi selama Pandemi Covid-19 ini, banyak kerja di rumah, contoh anak ibu sekolahnya daring dirumah saja, kalau minta tolong ibu mengajar anak karena ibu sedang mencuci pakaian suami ibu ini marah-marah seperti orang yang sudah bosan atau jenuh saja sama ibu dengan anak ibu, mungkin karena bertemu tiap hari dirumah, sebelumnya Pandemi Covid-19 suami ibu ini bekerja di Sangir jarang bertemu dia tidak seperti itu, lantaran itu ibu tidak tahan lagi, ibu gugat dia bercerai..." (Wawanca, Tanggal 12 Mei 2021).

Berdasarkan observasi peneliti pada tanggal 12 Mei 2021 di Kecamatan Sungai Pagu terlihat bahwa meningkatnya cerai gugat oleh pihak istri pada suami disebakan oleh faktor psikologis yakninya muncul rasa jenuh dan bosan ketika kehidupan di rumah tidak sejalan dengan kebiasaan yang biasa dilakukan pada saat sebelum masa Pandemi Covid-19, dimana sebelumnya suami bekerja di sektor publik karna ada pembatasan sosial berskala besar di Kecamatan Sungai Pagu harus berdiam diri di rumah namun tidak membantu istri dalam urusan rumah tangga dan mengurus anak melainkan munculnya rasa jenuh sehingga terjadi cerai gugat oleh pihak istri.

\section{Usia Pernikahan}

Pandemi Covid-19 menjadi permasalahan bagi semua orang, tidak hanya masalah kesehatan dan ekonomi melainkan juga masalah keutuhan rumah tangga, sejak masuk ke Indonesia pada akhir tahun 2019 hingga sekarang Pandemi Covid-19 menjadi permasalahan utama bagi ketahan keluarga khususnya keluarga yang baru menikah, dilansir dari (kompas.com, 2019) menteri agama Fachrul Razi angkat bicara mengenai peningkatan angka perceraian pada masa Pandemi, beliau meminta KUA setempat memberikan penyuluhan pada setiap pasangan saat masa pembinaan pranikah, dan setelah menikah, jika dibandingkan tahun 2019 sebelum masa Pandemi angka perceraian meningkat $20 \%$ pada pasangan yang baru menikah.

Begitu juga yang terjadi di Kecamatan Sungai Pagu Kecamatan Muara Labuh Kabupaten Solok Selatan, meningkatnya cerai gugat di Kecamatan Sungai Pagu pada masa Pandemi Covid-19 rata-rata terjadi pada usia pernikahan yang lebih muda, dimana pada masa Pandemi Covid-19 tahun 2020 dari 338 kasus cerai gugat yang terjadi di Kabupaten Solok 
Selatan paling banyak terjadi di Kecamatan Sungai Pagu yakninya berjumlah 63 kasus, dari 63 kasus perceraian tersebut didominasi berada pada rentang usia 16-64 tahun, selanjutnya dari data yang menikah pada tahun 2020 di Kabupaten Solok selatan lebih dari setengah yakninya usia muda rentang usia 19-24 tahun 83,89\% menjalani pernikahan (Pengadilan Agama Muara Labuh, 2021). Dari data di atas menunjukan faktor penyebab meningkatnya cerai gugat pada masa Pandemi Covid-19 terjadi karna usia pernikahan yang lebih muda, dimana usia tersebut rentan konfilk pada saat masa-masa kritis seperti pada saat Pandemi Covid-19 yang terjadi pada saat sekarang, seperti yang diungkapkan oleh WH (22 tahun), mengungkap bahwa:

“...Saya minta bercerai pada suami karena sikapnya belum dewasa, apalagi selama Pandemi Covid-19 ini dia tidak bekerja saya minta nafkah dia marahmarah, sampai-sampai bicara lebih baik bujangan gak pusing, dari sini dia terlihat tidak dewasa, makanya saya meggugat cerai..."(Wawancara, Tanggal 27 Mei 2021).

Berdasarkan observasi peneliti pada tanggal 27 Mei 2021 terlihat bahwa faktor penyebab cerai gugat pada masa Pandemi Covid-19 di Kecamatan Sungai Pagu Kecamatan Muara Labuh Kabupaten Solok selatan disebakan oleh usia pernikahan, dimana usia pernikahan muda di Kecamatan Sungai Pagu rentan terhadap konflik antar suami istri pada saat Pandemi Covid-19, hal itu disebabkan tidak siapnya pasangan suami istri yang menikah pada usia muda dalam menghadapi masa-masa kritis seperti saat masa Pandemi Covid-19 di Kecamatan Sungai Pagu Kecamatan Muara Labuh Kabupaten Solok Selatan.

Pembahasan mengenai cerai gugat yang disebabkan oleh menikah pada usia muda pada masa Pandemi Covid-19, maka proposisi yang dipakai adalah proposisi nilai. Proposisi nilai memberikan arti bahwa semakin tinggi nilai suatu tindakan, maka kian senang orang melakukan tindakan itu. Ketika pasangan sudah tidak lagi menghargai pasangannya seperti cerai gugat yang disebakan oleh menikah pada usia muda yang rentan dengan masalah keluarga maka pasangan tersebut memilih sesuatu yang bernilai baginya dibanding kepada keluarganya. Istri ketika cost kasih sayang kepada suami dengan menjaga komitmen berumah tangga, akan tetapi reward yang diinginkan dari suami tidak didapatkan maka pihak istri akan memilih untuk menggugat cerai, karena merasa dirugikan oleh prilaku suami.

\section{Fakor -Faktor Penyebab Cerai Gugat sebelum masa Pandemi Covid-19}

\section{Faktor Kekerasan Dalam Rumah Tangga (KDRT)}

Kekerasan dalam rumah tangga (KDRT) adalah kekerasan yang dilakukan di dalam rumah tangga baik oleh suami maupun oleh istri, menurut Annisa kekerasan dalam rumah tangga (KDRT) adalah segala bentuk tindak kekerasan yang terjadi atas dasar perbedaan jenis kelamin yang mengakibatkan rasa sakit atau penderitaan terutama terhadap perempuan termasuk ancaman, paksaan, pembatasan kebebasan baik yang terjadi dalam lingkungan publik maupun dosmetik (Manumpahi et al., 2016).

Kekerasan dalam rumah tangga(KDRT) dalam rumah tangga juga dialami oleh istri di Kecamatan Sungai Pagu Kabupaten Solok-Selatan. KDRT juga menjadi faktor penyebab istri menggugat cerai suami sebelum masa Pandemi Covid-19. Dari hasil Observasi dan wawancara yang peneliti lakukan pada tanggal 21 Mei 2021 pada pukul 08.00-10.00 wib di rumah kediaman ibu ML (34 tahun). Subjek menejelaskan bahwa Penyebab subjek 
menggugat cerai suami karena suami yang kerap melakukan kekerasan terhadap ibu ML. berikut penuturan wawancara dengan ibu ML:

\begin{abstract}
“...Penyebab ibu menggugat cerai suami karena dia melakukan kekerasan terhadap ibu, semnjak usahanya kurang jalan suami ibu tersebut, karena suami ibu suka melakukan kekerasan ke ibu itu menyebabkan ibu tidak sanggup lagisehingga ibu menggugat cerai suami ibuk..." (Wawancara Tanggal 19 Mei 2021).
\end{abstract}

Dari hasil observasi dan wawancara peneliti terhadap Istri yang melakukan cerai gugat sebelum masa Pandemi Covid-19 pada pukul 13. 00- 15.00 di ruang tamu, peneliti melihat memang istri yang melakukan cerai gugat memang mengalami tindak kekerasan dalam rumah tangga, karena saat dilakukan wawancara dan peneliti mengajukan beberapa pertanyaan mengenai penyebab subjek menggugat cerai suaminya istri tersebut langsung menangis dan menunjukkan bekas luka yang di alaminya dahulu ketika masih bersuami, hanya saja istri tersebut memilih jalan bercerai dan tidak melaporkan hal tersebut kepada pihak berwajib. Karena istri tersebut tidak mau ayah dari anak-anaknya mendapat hukuman seperti itu.

Berdaasarkan informasi dari beberapa informan di atas terlihat bahwa sebelum Pandemi Covid-19 menjadi salah satu faktor utama terjadinya cerai gugat di Kecamatan Sungai Pagu, suami melakukan kekerasan kepada istri sehingga menyebabkan subjek menggugat cerai suaminya. Suami yang memiliki masalah di luar rumah membuat suami menjadi tempramental dan suka menyakiti istrinya. Suami yang mengalami stres karena masalah keluarga dan masalah diluar rumah. Dari hasil wawancara peneliti menemukan sebelum masa pada masa pandemi suami salah satu faktor terjadinya cerai gugat oleh istri di Kecamatan sungai Pagu disebakan oleh KDRT yang dialami istri, sehingga hal tersebut membuat istri tidak sanggup lagi dan memilih jalan untuk menggugat cerai.

Berkatian dengan faktor-faktor penyebab KDRT bisa dikaji menggunakan teori pertukaran menurut George C Homans, dimana teori pertukaran memiliki 5 proposisi. Proposisi dari teori pertukaran Homans salah satunya adalah proposisi restu agresi. Proposisi restu agresi menjelaskan apabila seseorang memperoleh ganjaran yang diharapkan atau menerima hukuman yang tidak di inginkannya maka ia akan marah. Ia cendrung menunjukkan perilaku agresif dan hasil perilaku tersebut bernilai baginya. Apabila tindakan seseorang memperoleh ganjaran yang lebih besar dari yang diperkirakan atau tidak memperoleh hukuman yang diharapkannya, maka ia akan merasa senang. Proposisi ini melihat bahwa makin dirugikan seseorang dalam hubungannya dengan orang lain, maka besar kemungkinan orang tersebut akan mengembangkan emosi seperti marah.

Berdasarkan hasil wawancara dengan narasumber dapat dikaitkan dengan proposisi restu agresi bahwa ketika suami kehilangan pekerjaannya atau dirugikan dan tidak mendapatkan ganjaran ia akan memiliki sikap emosi sehingga membuatnya sering melakukan KDRT kepada istrinya. KDRT tersebut yang memperlihatkan suami memiliki perilaku agresif kepada istrinya.

\title{
Perselingkuhan
}

Pada sebelum masa Pandemi Covid-19 penyebab Cerai gugat oleh istri kepada suami adalah perselingkuhan yang dilakukan oleh suami. Hal ini akan bermuara pada ketidak harmonisan hubungan keduanya (Ghoffar, 2016). Perselingkuhan memberikan dampak buruk pada berbagai aspek kehidupan seluru anggota keluarga, diantaranya yaitu hancurnya masa 
depan anak-anak, rasa malu ditanggung keluarga besar, rusaknya karier, serta rusaknya tatanan sosial di masa mendatang (Fajri \& Mulyono, 2017).

Perselingkuhan umumnya terjadi pada anggota keluarga yang kurang memiliki kualitas keagamaan, lemahnya dasar cinta, sikap egois, komunikasi yang kurang lancar, tidak harmonis, emosi kurang stabil dan kurang mampu menyesuaikan diri. Pada prinsipnya setiap orang mengkehendaki kehidupan normal dan dapat diterima dalam kehidupan sosial. Dalam rumah tangga yang seharusnya saling menjaga komitmen dalam hubungan suami istri, namun justru hancur akibat perselingkuhan yang dilakukan oleh salah satu pihak (Urip Tri Jayanti, 2020). Berdasarkan hasil penelitian ditemukan bahwa faktor penyebab istri menggugat cerai suaminya adalah perselingkuhan, dimana istri dan suami sering bertemu dan akhirnya memicu rasa bosan dengan pasangan akhirnya memilih selingkuh dengan orang lain.

Berdasarkan hasil observasi dan wawancara yang telah dilakukan peneliti pada tanggal 18 Mei 2021 pada pukul 10.00-12.00 wib di rumah kediaman ibu EP yang sederhana yang terbuat dari semi permanen, peneliti menemukan data bahwa cerai gugat sebelum pada masa Pandemi Covid-19 karena perselingkuhan. hal tersebut seperti yang di alami oleh ibu EP (49 tahun). Penyebab subjek menggugat cerai suami karena suami yang kerap berselingkuh saat ibu EP bekerja sebagai karyawan di PT Suprame Solok Selatan karena bekerja sehari-hari dan tidak bersama suami sepanjang waktu terjadi perselingkuhan oleh suami. Suami yang berselingkuh di waktu senggang dan malam hari, kebiasaan suami tersebut ternyata sudah membawa masalah dikehidupan rumah tangga ibu EP. Ternyata suami sudah berselingkuh dengan wanita lain, karena perselingkuhan dan kejenuhan dalam rumah tangga tersebut membuat ibu EP menggugat cerai suaminya. Berikut penuturan wawancara dengan ibu EP:

“...Suami ibuk itu selingkuh dengan orang lain nak, dia kerja di PT dan dia merasa jenuh dan bosan kepada ibu. Karena jenuh dan bosan dia memutuskan untuk keluar rumah pergi bermain di waktu senggang dan di malam hari, karena sering seperti itu ibu curiga dia selingkuh, ternyata dugaan ibu selama ibi benar dia selingkuh. Karena selingkuh dan bosan dengan ibu dan tidak ada rasa sama ibu, ibu sakit hati dan mengugat cerainya...". (Wawancara Tanggal 18 Mei 2021).

Suami yang memilih wanita lain dibandingkan istrinya yang dirasa sudah bosan dan jenuh. Suami menganggap dengan selingkuh dia akan mendapatkan hal baru dan menyenangkan baginya untuk mengatasi rasa bosannya kepada istri. Sedangkan istri yang merasa suaminya sudah mengkhianati rumah tangganya akan memilih untuk menggugat cerai suaminya, karena istri menganggap rumah tangganya dengan suami sudah tidak bisa dipertahankan lagi.

Jika faktor perselingkuhan dibahas dengan teori pertukaran menurut Homan. Teori pertukaran menurut homans ada 5 Proposisi. Untuk membahas perselingkuhan maka proposisi yang dipakai adalah proposisi nilai. Proposisi nilai memberikan arti bahwa semakin tinggi nilai suatu tindakan, maka kian senang orang melakukan tindakan itu. Ketika suami selingkuh maka dia memilih sesuatu yang bernilai baginya dibanding kepada istrinya yang sudah mulai bosan. Hal tersebut membuat suami selingkuh.

Istri ketika cost kasih sayang kepada suami dengan menjaga komitmen berumah tangga diberikan akan tetapi reward yang diinginkan dari suami tidak didapatkan maka pihak istri akan memilih untuk menggugat cerai. Karena merasa dirugikan oleh prilaku suami. 
Fitria Afifah, Delmira Syafrini Faktor Penyebab Meningkatnya Cerai Gugat Pada Masa Pandemi Covid-19 di Kecamatan Sungai Pagu Kabupaten Solok Selatan

\section{Kesimpulan}

Berdasarkan penelitian yang telah dilaksanakan oleh penulis, maka kesimpulan yang dapat diambil dari skripsi ini adalah selama masa pandemi Covid-19 di Kecamatan Sungai Pagu kasus cerai gugat mengalami peningkatan dilihat dari data jumlah kasus cerai gugat yang masuk ke Pengadilan Agama Muara labuh. dibandingkan tahun sebelum Pandemi Covid-19 jumlah kasus pada tahun 2020 mengalami peningkatan.

Faktor penyebab meningkatnya cerai gugat pada masa Pandemi Covid-19 di Kecamatan Sungai Pagu ada beberapa faktor yaitu: Pertama adalah faktor ekonomi diantaranya suami tidak memberi nafkah, dan beban ganda yang dialami istri. Kedua faktor psikologis diantaranya munculnya rasa jenuh dan usia pernikahan. Selain faktor tersebut dari hasil wawancara dan observasi peneliti menemukan hal yang unik, faktor penyebab cerai gugat di Kecamatan Sungai Pagu sebelum masa Pandemi Covid-19 adalah dikarenakan suami bersellingkuh dan melakukan kekerasan dalam rumah tangga (KDRT).

\section{Daftar Pustaka}

Apriasari, H., \& Al-jannah, F. M. (2021). Divorce in the Covid-19 Pandemic Era: An Integrative Stud. 1(1), 1-11.

Davies, P. D. O. (2002). Multi-drug resistant tuberculosis. CPD Infection, 3(1), 9-12.

Fajri, F \& Mulyono, M. (2017). Selingkuh Sebagai Salah Satu Faktor Penyebab Perceraian. Studi Hukum Islam.

Ghoffar, G. (2016). Menyikapi Tingkah Laku Suami.

Goffar, M, A. (2017). Menyikapi tingkah laku suami. Jakarta: ID Almahira.

Gunarsa, G. (2014). Psikologi Praktis, Anak, Remaja dan Keluarga (BPK Gunung).

Hamzah, A. (2019). Metode Penelitian \& Pengembangan Research and Development Uji Coba Produk Kuantitatif dan Kualitatif Proses dan Hasil. Jakarta: Literasi Nusantara.

Huberrman A.M \& Miles, M. (1984). Analisis Data Kualitatif Terjemahan. Universitas Indonesia.

Kalmijin, K., \& Leove, L. (2015). Income dynamic in couples and the dissolution of marriage and cohabitation. Demografy.

Katalog BPS: 1102001.1310040.

Khazanah, K. (2020). Benarkah Angka Cerai Naik Selama Pandemi? ini Jawaban Badilag $M A$.

Konoras, A., Hukum, F., \& Sam, U. (2014). Telaah Tingginya Perceraian Di Sulawesi Utara (Studi Kasus Putusan Pengadilan Agama). LPPM Bidang EkoSosBudKum, 1(2), 55.

Lincoln, D. (2009). Handbook of Quantitative Research. Jakarta: Pustaka Pelajar.

Machmud, M. E. (2015). Transaksi Dalam Teori Exchange Behaviorism George Caspar Homans (Perspektif Ekonomi Syariah). Iqtishadia: Jurnal Kajian Ekonomi Dan Bisnis Islam STAIN Kudus, 8(2), 257-280.

Maimun, M., Toha, M., \& Arifin, M. (2019). Fenomena Tingginya Angka Cerai-Gugat dan Faktor Penyebabnya: Analisis Reflektif Atas Kasus-Kasus Perceraian di Madura. Islamuna: Jurnal Studi Islam, 5(2), 157. https://doi.org/10.19105/islamuna.v5i2.2105

Maimunah, S. (2019). Analisis Tingkat Perceraian Akibat Perkawinan di Bawah Umur di Pengadilan Agama Kota Tebing Tinggi. E-Jurnal Manajemen Universitas Udayana, $4(3), 1-21$. 
Fitria Afifah, Delmira Syafrini Faktor Penyebab Meningkatnya Cerai Gugat Pada Masa Pandemi Covid-19 di Kecamatan Sungai Pagu Kabupaten Solok Selatan

Manumpahi, E., Goni, S. Y. V., \& Pongoh, H. W. (2016). Kajian Kekerasan Dalam Rumah Tangga Terhadap Psikologi Anak di Desa Soakonora Kecamatan Jailolo Kabupaten Halmahera Barat. E-Journal "Acta Diurna,"5(1), 1.

Nuruzzaman, F. (2017). Cerai Gugat Di Pengadilan Agama Pontianak. Universitas Tanjungpura.

Rais, Isnawati. (2014). Tingginya Angka Cerai Gugat (Khulu') di Indonesia: Analisis Kritis terhadap Penyebab dan Alternatif Solusi Mengatasinya. Al-'Adalah, 12(1), 191-204.

Rais, Isnawirati. (2010). Tingginya Angka Cerai Gugat (Khulu) Di Indonesia; Analisis Kritis Penyebab Dan Alternatif Solusi Mengatasinya. Fakultas Syariah Dan Hukum UIN Syarif Hidayatullah, 191-204.

Saputra, A. (2018). hampir-Setengah-Juta-Orang-Bercerai-di-Indonesia-Sepanjang.

Sari, L. (2014a). Analisis Faktor-Faktor Yang Mempengaruhi Tingkat Cerai Gugat Di Kota Pekanbaru. 1(2), 1-21.

Sari, L. (2014b). Analisis faktor-faktor yang mempengaruhi tingkat cerai gugat di Kota Pekanbaru. 1(2), 1-21.

Shauqie, M. (2016). Faktor-Faktor Penyebab Tingginya Perkara Cerai Gugat (Studi Perkara Di Pa Bantul Tahun 2013-2015). Universitas Islam Negeri Sunan Kalijaga.

Sholahuddin, M. (2007). Asas Asas Ekonomi. Jakarta: Balai Pustaka.

Su'adah, S. (2005). Sosiologi Keluarga. Malang: Universitas Muhammadiyah Malang.

Urip, T. J. (2020). Analisis Faktor Penyebab Perceraian Pada Masa Pandemi Covid-19 di Kabupaten Banyumas. Ilmu Keluarga Dan Konseling.

Wahab, A. (2012). Analisis yudiris terhadap faktor-faktor penyebab tingginya tingkat cerai gugat di pengadilan agama Kabupaten Kediri.

Zuhdi, A. M. (2008). Memahami Hukum Perkawinan: Nikah, Talak, cerai, dan Rujuk menurut Hukum Islam Nomor 1 Tahun 2008. Jakarta: Al Bayan. 